\title{
Risk of cancer in patients with heart failure who use digoxin: A 10-year follow-up study and cell-based verification
}

\author{
Min-Huey Chung ${ }^{1}$, Yi-Wen Wang ${ }^{2}$, Yung-Lung Chang ${ }^{3}$, Shih-Ming Huang ${ }^{3}$ and \\ Wei-Shiang Lin ${ }^{4}$ \\ ${ }^{1}$ Graduate Institute of Nursing, College of Nursing, Taipei Medical University, Taipei 110, Taiwan, Republic of China \\ ${ }^{2}$ Department of Biology and Anatomy, National Defense Medical Center, Taipei City 114, Taiwan, Republic of China \\ ${ }^{3}$ Department of Biochemistry, National Defense Medical Center, Taipei City 114, Taiwan, Republic of China \\ ${ }^{4}$ Department of Medicine, Division of Cardiology, Tri-Service General Hospital, National Defense Medical Center, Taipei City \\ 114, Taiwan, Republic of China \\ Correspondence to: Wei-Shiang Lin, email: wslin545@ms27.hinet.net \\ Keywords: heart failure, digoxin, cancer, cell-based strategy, personalized medicine \\ Received: February 18, $2017 \quad$ Accepted: March 30, $2017 \quad$ Published: April 25, 2017 \\ Copyright: Chung et al. This is an open-access article distributed under the terms of the Creative Commons Attribution License 3.0 \\ (CC BY 3.0), which permits unrestricted use, distribution, and reproduction in any medium, provided the original author and \\ source are credited.
}

\section{ABSTRACT}

Heart failure (HF) is the leading cause of death in the world and digoxin remains one of the oldest therapies for HF. However, its safety and efficacy have been controversial since its initial use and there is uncertainty about its long-term efficacy and safety. Recently, the repositioning of cardiac glycosides is to function in anti-tumor activity via multiple working pathways. It is interesting to compare the potential effects of digoxin in clinical patients and cell lines. First, we analyze patient information retrieved from the National Health Insurance Research database of Taiwan between January 1, 2000 and December 31, 2000. This retrospective study included a study cohort (1,219 patients) and a comparison cohort. Our analytical data suggested that patients taking digoxin are at an increased risk of cancers, including breast, liver, and lung cancers, during the 10-year follow-up period. In contrast to the anti-tumor function of digoxin, we further examined the potential pathway of digoxin via the cell-based strategy using several breast cancer cell lines, including MCF-7, BT474, MAD-MB-231, and ZR-75-1. Digoxin consistently exerted its cytotoxicity to these four cell lines with various range of concentration. However, the proliferation of ZR75-1 cells was the only cell lines induced by digoxin and the others were dramatically suppressed by digoxin. The responsiveness of SRSF3 to digoxin might be involved with cell-type differences. In summary, we combined a cohort study for digoxin treatment for HF patients with a cell-based strategy that addresses the translation issue, which revealed the complexity of personalized medicine.

\section{INTRODUCTION}

Heart failure (HF), characterized by pulmonary congestion, dyspnea, and fatigue, is a clinical syndrome in which the myocardial pump function is inadequate to maintain and support the physiological requirements of an individual. Digoxin, as well as digitoxin, is an ancient and effective therapy for congestive HF via the inhibition of the plasma membrane $\mathrm{Na}^{+} / \mathrm{K}^{+}$-ATPase $[1,2]$. The signaling characteristics of $\mathrm{Na}^{+} / \mathrm{K}^{+}$-ATPase are distinct from its ion pumping activity and activate associated downstream signaling pathways $[1,3]$. In addition to the sustained increase in the level of intracellular calcium for immunogenic cell death and apoptosis of tumor cells [4-7], digoxin also exerts its anti-tumor functions via multiple mechanisms, including at the post-transcriptional and translational stages [8]. However, there is uncertainty about its long-term efficacy and safety for the treatment of HF.

The role of big data in healthcare is to build better health profiles and better predictive models around patients 
Table 1: Retrospective clinical studies assessing the impact of digoxin in breast and prostate cancers

\begin{tabular}{|c|c|c|c|c|}
\hline Cancer Type & $\begin{array}{c}\text { Number of } \\
\text { patients }\end{array}$ & HR, OR or RR, $(95 \%$ CI), p value & Notes & Ref \\
\hline & 175 & Not available & Use decreased death rate & 10 \\
\hline \multirow{4}{*}{ Breast } & 324 & $1.30,(1.14-1.46)$ & $\begin{array}{l}\text { Use increased risk among } \\
\text { postmenopausal women }\end{array}$ & 11 \\
\hline & 104,648 & $\begin{array}{c}1.39,(1.32-1.46) \\
\mathrm{ER}^{+}: 1.35,(1.26-1.45)\end{array}$ & $\begin{array}{l}\text { Use increased risk, mainly of } \\
\text { developing } \mathrm{ER}^{+} \text {lesions }\end{array}$ & 12 \\
\hline & 1,219 & $1.30,(1.05-1.62) \mathrm{p}<0.001$ & This study & \\
\hline & 1,006 & $p=0.046$ & $\begin{array}{l}\text { Inverse correlation between use } \\
\text { and survival }\end{array}$ & 13 \\
\hline \multirow[t]{2}{*}{ Prostate } & 47,884 & $\begin{array}{c}\text { Regular user: } 0.54,(0.37-0.79) \mathrm{p}<0.001 \\
\text { Users for }>10 \mathrm{y}: 0.76,(0.61-0.95)\end{array}$ & $\begin{array}{l}\text { Use (in particular } \geq 10 \mathrm{y} \text { ) } \\
\text { decreased risk }\end{array}$ & 14 \\
\hline & 1,219 & $0.75,(0.41-1.37)$ & This study & \\
\hline
\end{tabular}

so that doctors can predict epidemics, cure disease, improve the quality of life, and avoid preventable deaths [9]. There are many retrospective studies, including epidemiological and clinical, that have investigated whether the use of digoxin would increase or decrease incidences of several tumors [10-18], such as breast and prostate cancers (Table 1). In most cases, the use of digoxin decreased their incidence. Breast cancer was the only increased case, suggesting that digoxin resembles estrogen chemically and may have an estrogenic effect [12, 15-17]. Furthermore, the work of Biggar's laboratory has shown that consistently increased risks from digoxin use is marginally higher for estrogen receptor (ER) positive breast cancers $[12,15,16]$.

We take advantage of related clinical information regarding claims from the National Health Insurance (NHI) program, which was initiated by the Taiwanese government in 1995, is a compulsory single-payer system, and covers over $98 \%$ of the 23 million inhabitants in Taiwan [19]. Our retrospective study includes a study cohort and a comparison cohort. Our analytical data shows that the increased risk of cancers by digoxin during a 10-year follow-up period was found in breast, liver, and lung cancers. Finally, we examined the potential role of digoxin in the proliferation of breast cancer cell lines. The combination of this information and cell-based strategy could allow us to understand the working mechanisms as well as the side effects of clinical drugs.

\section{RESULTS}

\section{Digoxin and subsequent risk of cancers}

In 2000, we identified 1,219 pHF-Digo, patients with heart failure who have taken digoxin, and 2,942 pHF, the patients with heart failure who had not taken digoxin, in the comparison group (Table 2). Over half of pHFDigo were older than 65 years-old, $55.11 \%$ were female patients and $84.76 \%$ had a monthly income < US\$ 640 $(<$ NT\$ 20,000). After analyzing the characteristics of digoxin exposure in patients with heart failure in Taiwan in 2000, the variables of patients' age, income, region, and Charlson Comorbidity Index (CCI) were significant. Table 3 shows the incidence of patients with cancers during the 10-year follow-up period for pHF-Digo. The incidence of cancers among pHF-Digo was higher than in pHF (11.66 vs. 10.44 per 100 person-years). pHF-Digo had a significantly higher incidence of being diagnosed with cancers compared to $\mathrm{pHF}$ for each of the previously named variables. In addition, the AHR of males was significant, patients $\geq 65$ years-old, $<45$ years-old; and the group with a CCI score $\geq 3$ are significant.

\section{Cancers and subsequent risk of digoxin}

During 2000/1/1-12/31, to further analyze the relation between cumulative defined daily dose (DDD) of digoxin per year and heart failure patients with cancers, we identified 1,219 heart failure patients with digoxin dosage from all heart failure patients and divided them into 2 groups by the median of cumulative per year dose: 140 (Table 4). After adjusting for age, gender, income, region, urbanization, and $\mathrm{CCI}$, the results revealed that no significant differences were found in the Cox proportional hazard regression model in each group. Table 5 shows the incidence of cancers during the 10-year follow-up period for pHF-Digo. We found that the adjusted hazard ratio (AHR) for breast cancer among pHF-Digo was particularly high $(\mathrm{AHR}=15.28,95 \% \mathrm{CI}$ -11.72-42.29) compared with the control group. After adjusting for age, gender, income, region, urbanization, and $\mathrm{CCI}$, the results revealed significant differences were found for breast cancer $(\mathrm{AHR}=1.30,95 \%$ CI 1.05-1.62) and liver cancer $(\mathrm{AHR}=1.29 ; 95 \% \mathrm{CI} 1.03-1.62)$. There was also an increased risk of lung cancer among study patients compared with the control group $(\mathrm{CHR}$ (crude hazard ratio) $=1.38$; 95\% CI 1.11-1.7). However, there was no significantly increased risk of colorectal and gynecological cancers or no significantly decreased risk of prostate, bladder, and kidney cancers. 
Table 2: Characteristics of Digoxin exposure in heart failure patients in Taiwan from 2000/01/01-/12/31 (N=4,161)

\begin{tabular}{|c|c|c|c|c|c|c|c|}
\hline \multirow{3}{*}{ Variable } & \multirow{2}{*}{\multicolumn{2}{|c|}{$\frac{\text { All Heart Failure }}{(n=4,161)}$}} & \multicolumn{4}{|c|}{ Heart Failure } & \multirow{3}{*}{ p-value } \\
\hline & & & \multicolumn{2}{|c|}{ Digoxin $(n=1,219)$} & \multicolumn{2}{|c|}{ Non-Digoxin $(n=2,942)$} & \\
\hline & $\mathbf{n}$ & $\%$ & $\mathbf{n}$ & $\%$ & $\mathbf{n}$ & $\%$ & \\
\hline Age (years) & & & & & & & $<0.001$ \\
\hline$<45$ & 398 & 9.57 & 71 & 5.83 & 327 & 11.12 & \\
\hline $45-64$ & 1,428 & 34.32 & 340 & 27.89 & 1,088 & 36.98 & \\
\hline$\geq 65$ & 2,335 & 56.11 & 808 & 66.28 & 1,527 & 51.90 & \\
\hline Gender & & & & & & & 0.104 \\
\hline Female & 2,293 & 55.11 & 648 & 53.16 & 1,645 & 55.91 & \\
\hline Male & 1,868 & 44.89 & 571 & 46.84 & 1,297 & 44.09 & \\
\hline Incomes (US\$) & & & & & & & $<0.001$ \\
\hline $\begin{array}{c}\geq 1281(\geq \\
\text { NT\$ } 40,000)\end{array}$ & 204 & 4.90 & 46 & 3.77 & 158 & 5.37 & \\
\hline $\begin{array}{l}\quad 640-1280 \\
(\mathrm{NT} \$ 20,000- \\
39,999)\end{array}$ & 430 & 10.34 & 93 & 7.63 & 337 & 11.46 & \\
\hline $\begin{array}{l}<640(<\text { NT\$ } \\
20,000)\end{array}$ & 3,527 & 84.76 & 1,080 & 88.60 & 2,447 & 83.17 & \\
\hline Region & & & & & & & $<0.001$ \\
\hline Northern & 1,676 & 40.28 & 453 & 37.16 & 1,223 & 41.57 & \\
\hline Center & 1,191 & 28.62 & 399 & 32.73 & 792 & 26.92 & \\
\hline South & 1,141 & 27.42 & 317 & 26.00 & 824 & 28.01 & \\
\hline East & 153 & 3.68 & 50 & 4.20 & 103 & 3.50 & \\
\hline Urbanization & & & & & & & 0.124 \\
\hline Urban & 2,118 & 50.90 & 596 & 48.89 & 1,522 & 51.73 & \\
\hline Suburban & 1,546 & 37.16 & 461 & 37.82 & 1,085 & 36.88 & \\
\hline Rural & 497 & 11.94 & 162 & 13.29 & 335 & 11.39 & \\
\hline CCI & & & & & & & $<0.001$ \\
\hline$<3$ & 1,357 & 32.61 & 328 & 26.91 & 1,029 & 34.98 & \\
\hline$\geq 3$ & 2,804 & 67.39 & 891 & 73.09 & 1,913 & 65.02 & \\
\hline Total & 4,161 & 100.00 & 1,219 & 100.00 & 2,942 & 100.00 & \\
\hline
\end{tabular}

CCI, Charlson Comorbidity Index scores.

\section{The proliferative effects by digoxin on the various breast cancer cell lines}

Digoxin resembles estrogen chemically and may have an estrogenic effect. It is better to understand whether digoxin has a positive effect on breast cancer cell proliferation. We examined four well-known breast cancer cell lines, including MCF7, BT474, MDA-MB-231, and ZR-75-1. MCF7 and ZR-75-1 cells are categorized into the luminal A subtype; BT474 cell line is categorized into the luminal B subtype; and MDA-MB-231 is categorized into the basal-like subtype. We first analyzed and measured the IC50 value of digoxin in the four breast cancer cell lines. The IC50 value was $60 \mathrm{nM}$ for MCF7 cells; $230 \mathrm{nM}$ for BT474 cells; $80 \mathrm{nM}$ for MDA-MB-231 cells; and $170 \mathrm{nM}$ for ZR-75-1 cells (Figure 1).

The cell cycle profile of these four cell lines were treated with digoxin and analyzed via the BrdU-FITC/7- 
Table 3: Cancer risk associated with digoxin use in heart failure patients in Taiwan

\begin{tabular}{|c|c|c|c|c|c|c|c|c|}
\hline \multirow{2}{*}{ Variable } & \multicolumn{3}{|c|}{ HF Patient with Digoxin } & \multicolumn{3}{|c|}{ HF Patient with Non-Digoxin } & \multicolumn{2}{|c|}{ Hazard ratio and $95 \% \mathrm{CI}$} \\
\hline & Cases & PY & Incidence & Cases & PY & Incidence & $\mathrm{CHR}^{\mathrm{a}}$ & $\mathbf{A H R} \mathbf{R}^{\mathbf{b}}$ \\
\hline \multicolumn{9}{|l|}{ Age (years) } \\
\hline$<45$ & 5 & 689.4 & 0.73 & 26 & 3408.8 & 0.76 & Ref. & Ref. \\
\hline $45-64$ & 46 & 3170 & 1.45 & 147 & 10973.8 & 1.34 & $\begin{array}{l}1.83(1.25- \\
2.67)^{*}\end{array}$ & $\begin{array}{c}1.69(1.16- \\
2.48)^{*}\end{array}$ \\
\hline$\geq 65$ & 148 & 6593.9 & 2.24 & 307 & 13790 & 2.23 & $\begin{array}{c}3.13(2.17- \\
4.50)^{* *}\end{array}$ & $\begin{array}{c}2.61(1.80- \\
3.80)^{* *}\end{array}$ \\
\hline \multicolumn{9}{|l|}{ Gender } \\
\hline Female & 110 & 5585.6 & 1.97 & 230 & 16078 & 1.43 & Ref. & Ref. \\
\hline Male & 89 & 4867.7 & 1.83 & 250 & 12094.6 & 2.07 & $\begin{array}{c}1.29(1.11- \\
1.50)^{* *}\end{array}$ & $\begin{array}{l}1.27(1.09- \\
1.48)^{*}\end{array}$ \\
\hline \multicolumn{9}{|l|}{ Incomes (US\$) } \\
\hline $\begin{array}{l}\geq 1281(\geq \mathrm{NT} \$ \\
40,000)\end{array}$ & 6 & 443.6 & 1.35 & 23 & 1582.8 & 1.45 & Ref. & Ref. \\
\hline $\begin{array}{l}640-1280 \text { (NT\$ } \\
20,000-39,999)\end{array}$ & 11 & 865.4 & 1.27 & 46 & 3380.9 & 1.36 & $0.94(0.60-1.47)$ & $\begin{array}{c}0.87(0.56- \\
1.37)\end{array}$ \\
\hline $\begin{array}{l}<640(<\text { NT\$ } \\
20,000)\end{array}$ & 182 & 9144.3 & 1.99 & 411 & 23208.9 & 1.77 & $1.32(0.91-1.91)$ & $\begin{array}{c}1.00(0.68- \\
1.48)\end{array}$ \\
\hline \multicolumn{9}{|l|}{ Region } \\
\hline Northern & 77 & 3831 & 2.01 & 211 & 11659.6 & 1.81 & Ref. & Ref. \\
\hline Center & 65 & 3432.6 & 1.89 & 115 & 7718.5 & 1.49 & $0.86(0.72-1.04)$ & $\begin{array}{c}0.81(0.67- \\
0.99)^{*}\end{array}$ \\
\hline South & 49 & 2752.5 & 1.78 & 143 & 7803.4 & 1.83 & $0.98(0.82-1.17)$ & $\begin{array}{c}0.91(0.75- \\
1.10)\end{array}$ \\
\hline East & 8 & 437.2 & 1.83 & 11 & 991.1 & 1.11 & $0.71(0.45-1.14)$ & $\begin{array}{c}0.71(0.45- \\
1.14)\end{array}$ \\
\hline \multicolumn{9}{|l|}{ Urbanization } \\
\hline Urban & 100 & 5109 & 1.96 & 243 & 14668.1 & 1.66 & Ref. & Ref. \\
\hline Suburban & 71 & 3957 & 1.79 & 179 & 10320 & 1.73 & $1.01(0.86-1.19)$ & $\begin{array}{c}0.96(0.81- \\
1.14)\end{array}$ \\
\hline Rural & 28 & 1387.3 & 2.02 & 58 & 3184.5 & 1.82 & $1.09(0.86-1.38)$ & $\begin{array}{c}1.08(0.85- \\
1.37)\end{array}$ \\
\hline \multicolumn{9}{|l|}{ CCI } \\
\hline$<3$ & 36 & 3063 & 1.18 & 105 & 10470.7 & 1.00 & Ref. & Ref. \\
\hline$\geq 3$ & 163 & 7390.3 & 2.21 & 375 & 17701.9 & 2.12 & $\begin{array}{c}2.13(1.77- \\
2.57)^{* *}\end{array}$ & $\begin{array}{l}1.86(1.54- \\
2.25)^{* *}\end{array}$ \\
\hline All & 199 & 10453.3 & 1.90 & 480 & 28172.6 & 1.70 & $1.16(0.98-1.37)$ & $\begin{array}{c}1.04(0.88- \\
1.23)\end{array}$ \\
\hline
\end{tabular}

PY, person-years at risk per 100 person-years, HF, Heart Failure

a. CHR: Crude hazard ratio was calculated by using stratified Cox proportional hazards regression

b. AHR (adjusted hazard ratio): Controlling the variables of age, gender, income, region, urbanization, cci, *: $\mathrm{p}<0.05 * *$ : $\mathrm{p}<0.001$ 
Table 4: Relation between cumulative defined daily dose of digoxin per year and HF patients with cancers

\begin{tabular}{|c|c|c|c|c|c|}
\hline Dose & No. of Cases & PY & Incidence $^{\mathrm{a}}$ & CHR (95\% C.I.) & $\operatorname{AHR}(95 \%$ C.I. $)$ \\
\hline \multicolumn{6}{|l|}{ ALL } \\
\hline $\mathrm{DDD}<140$ & 93 & 5058.4 & 1.84 & Ref. & Ref. \\
\hline $\mathrm{DDD} \geq 140$ & 106 & 5394.9 & 1.96 & $1.06(0.80-1.40)$ & $1.12(0.85-1.49)$ \\
\hline \multicolumn{6}{|l|}{ Age $<45$} \\
\hline $\mathrm{DDD}<140$ & 3 & 292.9 & 1.02 & Ref. & Ref. \\
\hline $\mathrm{DDD} \geq 140$ & 2 & 396.5 & 0.50 & $0.51(0.08-3.02)$ & $0.21(0.02-2.87)$ \\
\hline \multicolumn{6}{|l|}{$45 \leq$ Age $<65$} \\
\hline $\mathrm{DDD}<140$ & 23 & 1571 & 1.46 & Ref. & Ref. \\
\hline $\mathrm{DDD} \geq 140$ & 23 & 1599 & 1.44 & $0.98(0.55-1.74)$ & $1.05(0.59-1.89)$ \\
\hline \multicolumn{6}{|l|}{ Age $\geq 65$} \\
\hline $\mathrm{DDD}<140$ & 67 & 3194.5 & 2.10 & Ref. & Ref. \\
\hline $\mathrm{DDD} \geq 140$ & 81 & 3399.4 & 2.38 & $1.12(0.81-1.55)$ & $1.17(0.84-1.63)$ \\
\hline \multicolumn{6}{|l|}{ Female } \\
\hline $\mathrm{DDD}<140$ & 47 & 2679.9 & 1.75 & Ref. & Ref. \\
\hline $\mathrm{DDD} \geq 140$ & 63 & 2905.7 & 2.17 & $1.24(0.85-1.81)$ & $1.32(0.90-1.93)$ \\
\hline \multicolumn{6}{|l|}{ Male } \\
\hline $\mathrm{DDD}<140$ & 46 & 2378.5 & 1.93 & Ref. & Ref. \\
\hline $\mathrm{DDD} \geq 140$ & 43 & 2489.2 & 1.73 & $0.88(0.58-1.33)$ & $0.93(0.61-1.42)$ \\
\hline \multicolumn{6}{|l|}{$\mathrm{CCI}<3$} \\
\hline $\mathrm{DDD}<140$ & 12 & 1222.3 & 0.98 & Ref. & Ref. \\
\hline $\mathrm{DDD} \geq 140$ & 24 & 1840.7 & 1.30 & $1.34(0.67-2.67)$ & $1.25(0.62-2.53)$ \\
\hline \multicolumn{6}{|l|}{$\mathrm{CCI} \geq 3$} \\
\hline $\mathrm{DDD}<140$ & 81 & 3836.1 & 2.11 & Ref. & Ref. \\
\hline $\mathrm{DDD} \geq 140$ & 82 & 3554.2 & 2.31 & $1.09(0.80-1.48)$ & $1.08(0.79-1.48)$ \\
\hline
\end{tabular}

CHR: Crude hazard ratio, The median of cumulative per year dose: 140, HF, Heart Failure

AHR (adjusted hazard ratio): Controlling the variables of age, gender, income, region, urbanization, cci *: $\mathrm{p}<0.05 * *$ : $\mathrm{p}<0.001$

a: person-years at risk per 100 person-years

DDD, defined daily dose

AAD staining method (Figure 2). The ZR-75-1 cell line was the only breast cell line to consistently increase the S phase population by digoxin, accompanied with a decreasing G1 phase population. In contrast, MCF7, BT474, and MDAMB-231 cells decreased the $S$ phase population by digoxin, accompanied with an increasing G1 phase population. We further verified the digoxin effect on the proliferation of breast cancer cell via the BrdU incorporation from Figure 2 (Figure 3). These findings reconfirmed that digoxin had the ability to induce the proliferation of ZR-75-1 cells, but not in the other three cell lines.
Our previous work provided several lines of evidence for digoxin to function in cellular cytotoxicity via the SRSF3-dependent pathway. ZR-75-1 cells were the only tested breast cell line to fit the increasing risk of breast cancer by digoxin. Compared with four breast cancer cell lines using RT-PCR and Western blotting analysis, there was no apparent $S R S F 3$ premature truncated construct and p53 $\beta$ PCR bands in ZR-75-1 cells (Figure 4). In addition to the degradation of p53 and p21 proteins by digoxin, Snail was the new target gene and protein in ZR-75-1 cells, as well as MCF7 and MDA- 
Table 5: Incidence and CHR, AHR for cancer among the sampled patients, according to cancer type, during 8-year followed up period

\begin{tabular}{|c|c|c|c|}
\hline Presence of cancer & $\begin{array}{c}\text { Total } \\
(n=4,161)\end{array}$ & $\begin{array}{l}\text { HF with Digoxin } \\
(n=1,219)\end{array}$ & $\begin{array}{c}\text { HF with Non-Digoxin } \\
(\mathrm{n}=2,942)\end{array}$ \\
\hline Lung Cancer (n,\%) & $125,3.00 \%$ & $42,3.45 \%$ & $83,2.82 \%$ \\
\hline Incidence per 100 person-years & 1.54 & 1.75 & 1.46 \\
\hline $\mathrm{CHR}^{\mathrm{a}}(95 \% \mathrm{CI})$ & - & $1.38(1.11-1.7)^{*}$ & 1.00 \\
\hline $\operatorname{AHR}^{\mathrm{b}}(95 \% \mathrm{CI})$ & - & $1.21(0.98-1.50)$ & 1.00 \\
\hline Breast Cancer (n,\%) & $30,0.72 \%$ & $8,0.66 \%$ & $22,0.75 \%$ \\
\hline Incidence per 100 person-years & 1.43 & 1.44 & 1.43 \\
\hline $\mathrm{CHR}^{\mathrm{a}}(95 \% \mathrm{CI})$ & - & $1.47(1.18-1.83)^{* *}$ & 1.00 \\
\hline $\mathrm{AHR}^{\mathrm{b}}(95 \% \mathrm{CI})$ & - & $1.30(1.05-1.62)^{*}$ & 1.00 \\
\hline Liver Cancer (n,\%) & $97,2.33 \%$ & $34,2.79 \%$ & $63,2.14 \%$ \\
\hline Incidence per 100 person-years & 1.49 & 1.61 & 1.42 \\
\hline $\mathrm{CHR}^{\mathrm{a}}(95 \% \mathrm{CI})$ & - & $1.46(1.17-1.83)^{* *}$ & 1.00 \\
\hline $\operatorname{AHR}^{\mathrm{b}}(95 \% \mathrm{CI})$ & - & $1.29(1.03-1.62)^{*}$ & 1.00 \\
\hline Colorectal Cancer (n,\%) & $149,3.58 \%$ & $43,3.53 \%$ & $106,3.60 \%$ \\
\hline Incidence per 100 person-years & 1.57 & 1.67 & 1.54 \\
\hline $\mathrm{CHR}^{\mathrm{a}}(95 \% \mathrm{CI})$ & - & $1.13(0.80-1.62)$ & 1.00 \\
\hline $\mathrm{AHR}^{\mathrm{b}}(95 \% \mathrm{CI})$ & - & $1.01(0.70-1.44)$ & 1.00 \\
\hline Prostate Cancer (n,\%) & $59,1.42 \%$ & $14,1.15 \%$ & $45,1.53 \%$ \\
\hline Incidence per 100 person-years & 1.63 & 1.55 & 1.66 \\
\hline $\mathrm{CHR}^{\mathrm{a}}(95 \% \mathrm{CI})$ & - & $0.85(0.47-1.55)$ & 1.00 \\
\hline $\operatorname{AHR}^{b}(95 \% \mathrm{CI})$ & - & $0.75(0.41-1.37)$ & 1.00 \\
\hline Gynecology Cancer (n,\%) & $34,0.82 \%$ & $14,1.15 \%$ & $20,0.68 \%$ \\
\hline Incidence per 100 person-years & 1.85 & 2.26 & 1.65 \\
\hline $\mathrm{CHR}^{\mathrm{a}}(95 \% \mathrm{CI})$ & - & $1.87(0.94-3.70)$ & 1.00 \\
\hline $\operatorname{AHR}^{b}(95 \% \mathrm{CI})$ & - & $2.01(1.02-4.20)$ & 1.00 \\
\hline Bladder Cancer (n,\%) & $32,0.77 \%$ & $8,0.66 \%$ & $24,0.82 \%$ \\
\hline Incidence per 100 person-years & 1.48 & 1.65 & 1.44 \\
\hline $\mathrm{CHR}^{\mathrm{a}}(95 \% \mathrm{CI})$ & - & $0.95(0.42-2.11)$ & 1.00 \\
\hline $\operatorname{AHR}^{\mathrm{b}}(95 \% \mathrm{CI})$ & - & $0.82(0.37-1.84)$ & 1.00 \\
\hline Kidney Cancer (n,\%) & $30,0.72 \%$ & $5,0.41 \%$ & $25,0.85 \%$ \\
\hline Incidence per 100 person-years & 1.52 & 1.87 & 1.46 \\
\hline $\mathrm{CHR}^{\mathrm{a}}(95 \% \mathrm{CI})$ & - & $0.55(0.21-1.45)$ & 1.00 \\
\hline $\operatorname{AHR}^{b}(95 \% \mathrm{CI})$ & - & $0.47(0.18-1.24)$ & 1.00 \\
\hline Oral Cancer (n,\%) & $18,0.43 \%$ & $5,0.41 \%$ & $13,0.44 \%$ \\
\hline Incidence per 100 person-years & 1.39 & 1.33 & 1.42 \\
\hline $\mathrm{CHR}^{\mathrm{a}}(95 \% \mathrm{CI})$ & - & $1.13(0.40-3.18)$ & 1.00 \\
\hline $\operatorname{AHR}^{\mathrm{b}}(95 \% \mathrm{CI})$ & - & $1.12(0.39-3.18)$ & 1.00 \\
\hline
\end{tabular}

(Continued) 


\begin{tabular}{lccc}
\hline Presence of cancer & $\begin{array}{c}\text { Total } \\
(\mathbf{n = 4 , 1 6 1 )}\end{array}$ & $\begin{array}{c}\text { HF with Digoxin } \\
(\mathbf{n = 1 , 2 1 9 )}\end{array}$ & $\begin{array}{c}\text { HF with Non-Digoxin } \\
(\mathbf{n = 2 , 9 4 2})\end{array}$ \\
\hline Other Cancer (n,\%) & $672,16.15 \%$ & $195,16.00 \%$ & $477,16.21 \%$ \\
Incidence per 100 person-years & 1.62 & 1.78 & 1.56 \\
$\mathrm{CHR}^{\mathrm{a}}(95 \% \mathrm{CI})$ & - & $1.14(0.96-1.35)$ & 1.00 \\
$\mathrm{AHR}^{\mathrm{b}}(95 \% \mathrm{CI})$ & - & $1.03(0.87-1.21)$ & 1.00 \\
\hline
\end{tabular}

${ }^{a} \mathrm{CHR}$ : Crude hazard ratio was calculated by using stratified Cox proportional hazards regression, HF: Heart Failure b.AHR (adjusted hazard ratio): Controlling the variables of age, gender, income, region, urbanization, cci, *: $\mathrm{p}<0.05$ **: $\mathrm{p}<0.001$

ICD-9-code: Prostate Cancer:185 Liver Cancer:155 Gynecology Cancer:180.182.183 Breast Cancer:174 Lung Cancer:162 Colorectal Cancer:153.154 Oral Cancer:145.141 Bladder Cancer:188 Kidney Cancer:189 Gall bladder Cancer:156

MB-231 cells. In the Western blotting analysis, there was no change of $\mathrm{p} 53$, p21, and snail proteins in BT474 cells.

\section{DISCUSSION}

Digoxin has $\mathrm{Na}^{+} / \mathrm{K}^{+}$-ATPase-independent effects $[1,2]$. Cumulative studies support the anti-tumor functions of digoxin. Our previous studies have revealed that they deplete SRSF3 protein as well as at the posttranscriptional level via downregulation of SRSF3 gene and protein expression which alternatively splices p 53 gene and protein from $\alpha$ into $\beta$ isoform [8,20-22]. Up to now, there are many retrospective studies, including epidemiological and clinical, that have elucidated most cases and indicated that the use of digoxin decreased incidences [11, 16-18, 23-26]. In this study, we used clinical information from the NHI program of Taiwan to find several cancers, such as breast, liver, and lung, were positively correlated with the digoxin treatment. The trend is against our previous work, which revealed the anti-tumor function of digoxin in several cancer cell lines, but is consistent with many studies [8, 15, 23, 25]. Furthermore, we verified the potential role of digoxin in four breast cancer cell lines as follows: MCF-7, BT474, MDA-MB-231, and ZR-75-1. Our data reveals that digoxin had the ability to induce the proliferation of ZR75-1 cells, not the other three cell lines; because there is no SRSE3/p53 pathway. Our findings support the notion that breast cancer encompasses a group of heterogeneous diseases, which can be demonstrated at the molecular, histopathologic, and clinical levels.

The discovery of five distinct subtypes of breast carcinomas (Luminal A, Luminal B, HER2 overexpression, Basal-like, and Normal-like) using wholegenome analysis; each with unique recognizable phenotypes and clinical outcomes [27]. Up to now, 17 commonly used breast cancer cell lines (468, AU 565, BT-20, BT-474, BT-483, HBL101, HS598T, MCF-7, MCF-10A, MCF10F, MCF-12A, MDA-MB-231, MDA-
MB-231-UR, MDA-MB-453, MDA-MD-435, SKBR3 , and ZR-75-1) are cultured in an appropriate medium $[27,28]$. Based on the expression of ER, progesterone receptor (PR) and HER 2, BT-474 is triple positive, MDANA-231 is triple negative, and MCF-7 and ZR-75-1 are positive of ER and PR in this study. The inconsistent proliferation response by digoxin in MCF-7 (luminal A) and ZR-75-1 (luminal B) cell lines was found, suggesting the heterogeneity of gene might play an important role in these two cell lines.

Clinical and biologic heterogeneity in breast carcinomas is also present among the different breast cancer cell lines, and can be revealed by gene expression profiling and IHC analysis [27, 28]. In addition to ER, PR, and HER2, many genes, including p53, have become important predictors and prognostic markers for breast cancer. The work of the Troester group has demonstrated that MCF-7 and ZR-75-1 cells showed a stronger p53regulated signature following doxorubicin treatment [29]. These inherent differences in p53-dependent targets could lead to different selection pressure for p53 loss in these two wild-type p53 cell line, suggesting that intrinsic heterogeneity of p53 signaling across breast cancer subtypes. In addition to p53 protein itself, Weiss's work has identified that a molecular bypass Snaill suppresses the anti-proliferative and pro-apoptotic effects exerted by wild-type p53 in breast cancer, revealing that Snail1dependent regulation of $\mathrm{p} 53$ activity probably impacts multiple arms of the carcinoma phenotype [30]. A population-base study showed the divergent rates of p53 mutation by breast cancer subtype and the prevalence of the basal-like and luminal A subtypes was strongly influenced by race and menopausal status [17]. Our work suggests that the SRSF3-p53 pathway might be another possibility to verify this in the future.

The current study had some limitations. Our nationwide population-based data from Taiwan might not be generalizable to other ethnic groups. In addition, this database lacked information of smoking, pregnancies, 


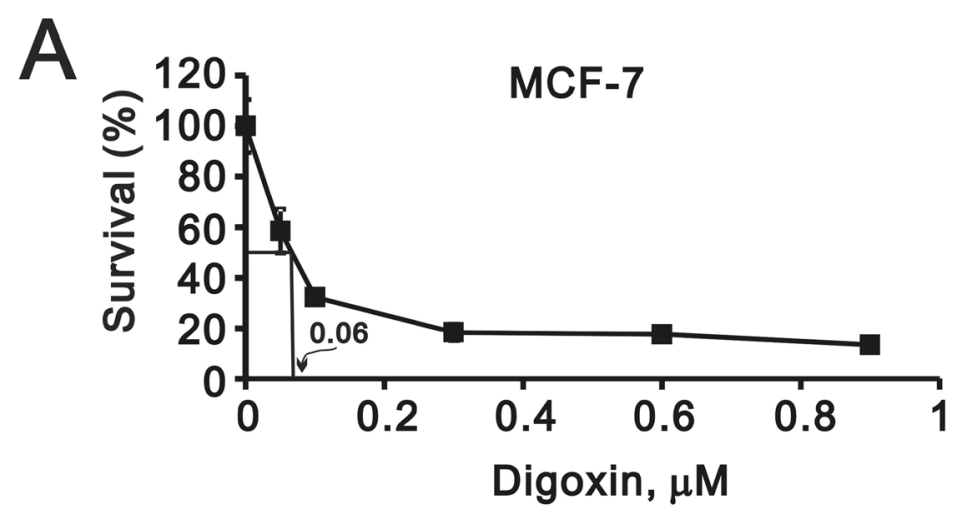

B
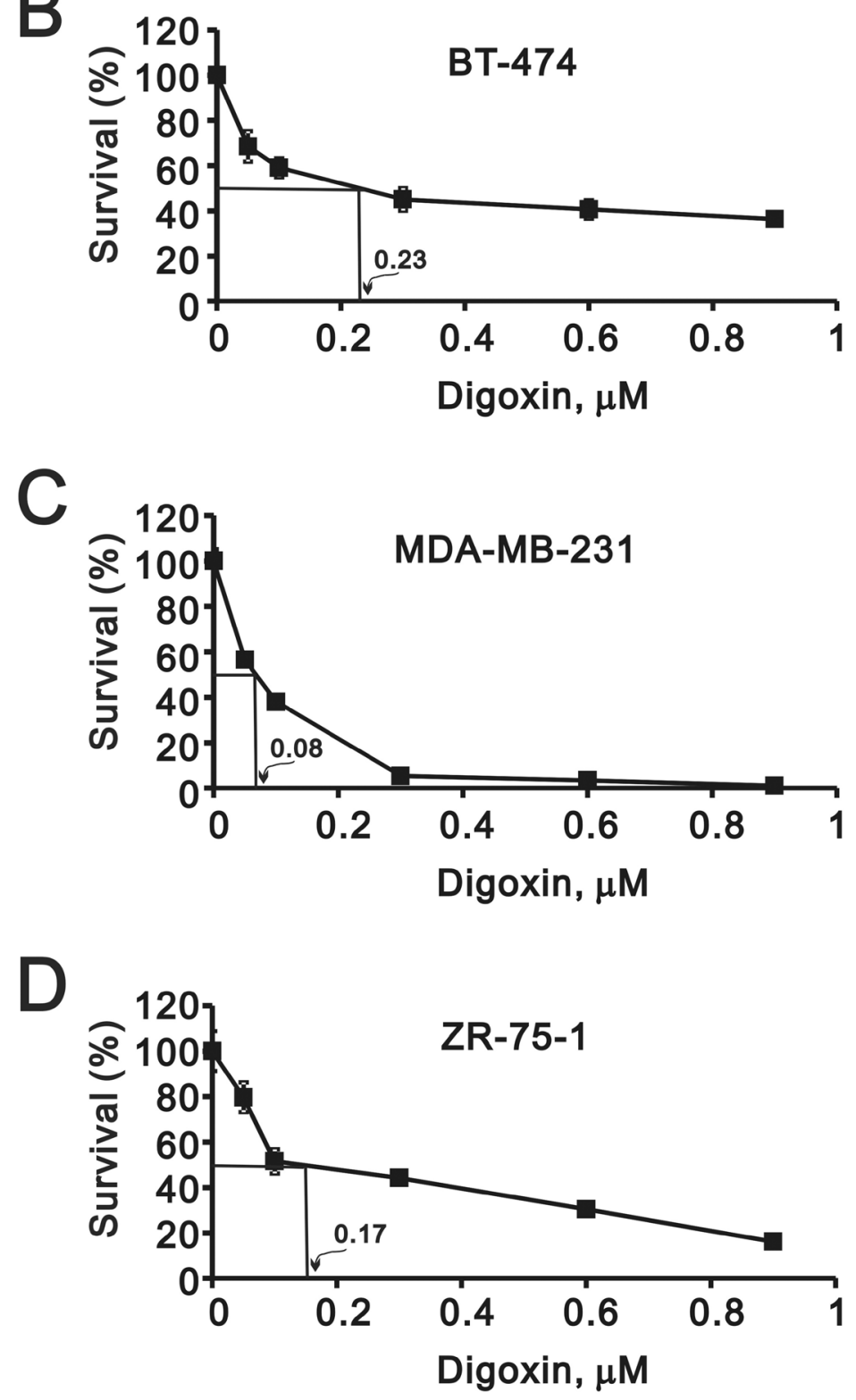

Figure 1: Potential effects of digoxin on the growth rate of various breast cancer cells. Breast cells (A) MCF-7, (B) BT-474, (C) MDA-MB-231, and (D) ZR-75-1 were treated with indicated concentrations of digoxin for $72 \mathrm{~h}$, MTS assay was performed at the time indicated. The IC50 value was shown in the plot. 


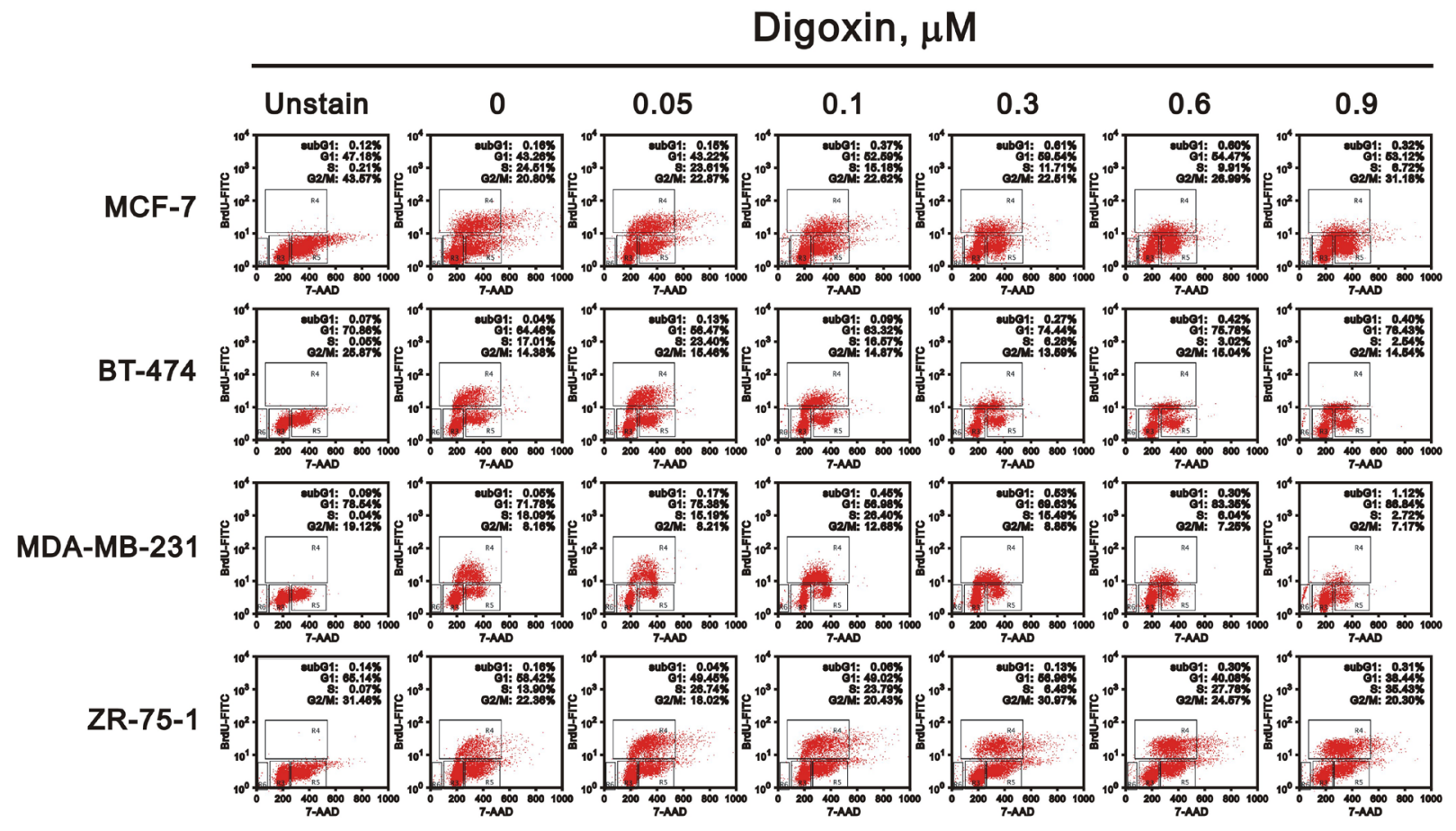

Figure 2: Potential effects of digoxin on the cell cycle profile of various breast cancer cells. Four breast cells (MCF-7, BT474, MDA-MB-231, and ZR-75-1) were treated with indicated concentrations of digoxin for $48 \mathrm{~h}$. The cells were collected and subjected to the 7-AAD staining flow-cytometry analysis to determine the population of various cell cycle phases. The results are representative of two independent experiments.

Digoxin, $\mu \mathrm{M}$

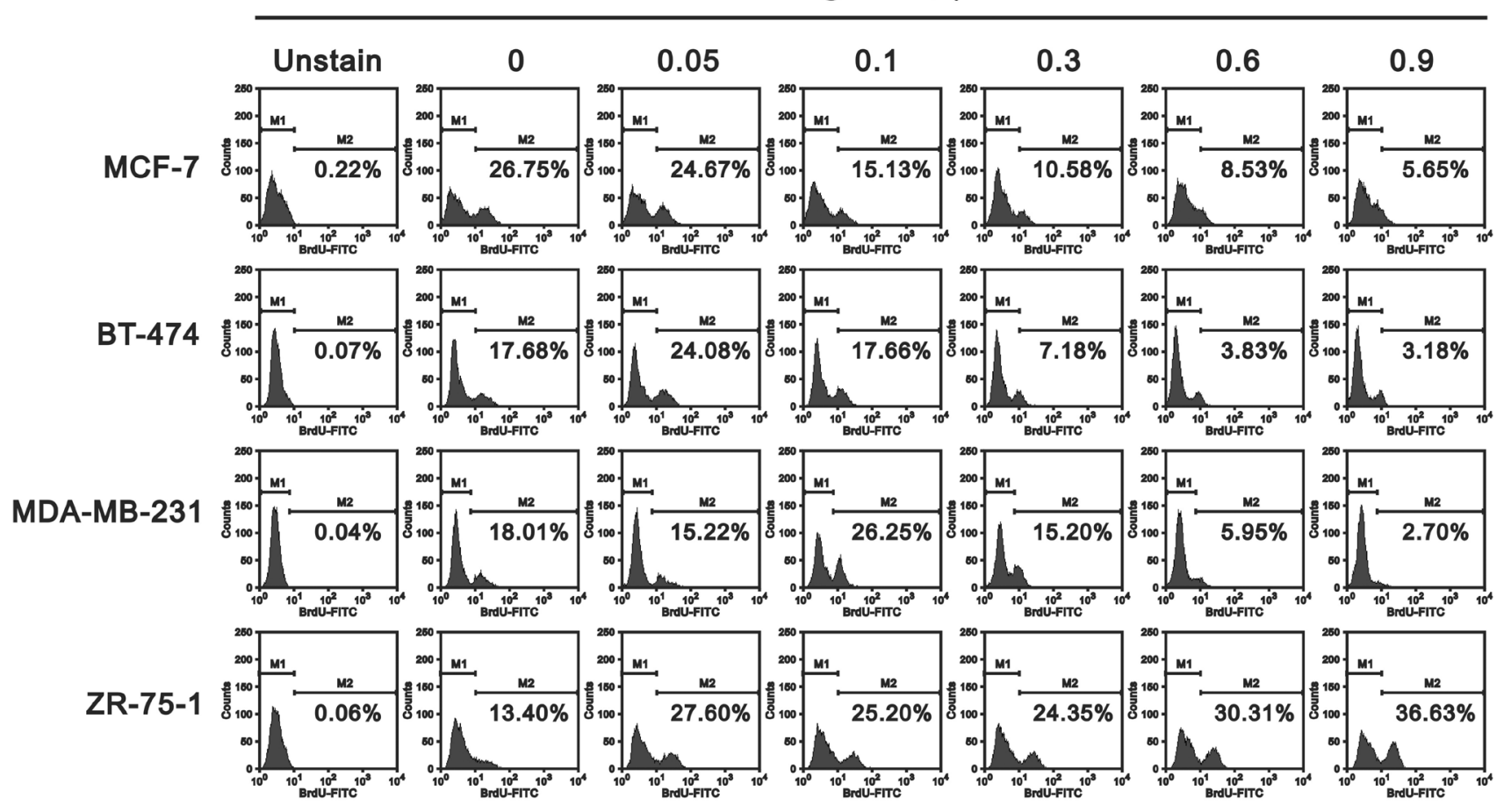

Figure 3: Potential effects of digoxin on the proliferation of various breast cancer cells. The same cells shown in Figure 2 were collected and subjected to the BrdU flow-cytometry analysis for the determination of the proliferation rate (M2). The results are representative of two independent experiments. 
Table 6: PCR primers used in this study

\begin{tabular}{|c|c|}
\hline Gene name & Primer sequence $\left(5^{\prime} \rightarrow 3^{\prime}\right)$ \\
\hline$p 53 \alpha$ & $\begin{array}{l}\text { Forward: 5'-GATGAAGCTCCCAGAATGCCAGAG-3' } \\
\text { Reverse: 5'-GAGTTCCAAGGCCTCATTCAGCTC-3' }\end{array}$ \\
\hline$p 53 \beta$ & $\begin{array}{l}\text { Forward: 5'-ATGGAGGAGCCGCAGTCAGAT-3' } \\
\text { Reverse: 5'-TTTGAAAGCTGGTCTGGTC-3' }\end{array}$ \\
\hline$G A P D H$ & $\begin{array}{l}\text { Forward: 5'-CTTCATTGACCTCAACTAC-3' } \\
\text { Reverse: 5'-GCCATCCACAGTCTTCTG-3' }\end{array}$ \\
\hline SRSF3 & $\begin{array}{l}\text { Forward: 5'-ATGCATCGTGATTCCTGTCCATTG-3' } \\
\text { Reverse: 5'-CTATTTCCTTTCATTTGACCTAGATC-3' }\end{array}$ \\
\hline Snail & $\begin{array}{l}\text { Forward: 5'-ATGCCGCGCTCTTTCCTCGTCAGG-3' } \\
\text { Reverse: 5'-TCAGCGGGGACATCCTGAGCAGCC-3' }\end{array}$ \\
\hline E-cadherin & $\begin{array}{l}\text { Forward: 5'-CCTGGGACTCCACCTACAGA-3 } \\
\text { Reverse: 5'-GGATGACACAGCGTGAGAGA-3' }\end{array}$ \\
\hline$p 21$ & $\begin{array}{l}\text { Forward: 5'-CTGAGCCGCGACTGTGATGCG-3' } \\
\text { Reverse: 5'-GGTCTGCCGCCGTTTTCGACC-3' }\end{array}$ \\
\hline
\end{tabular}
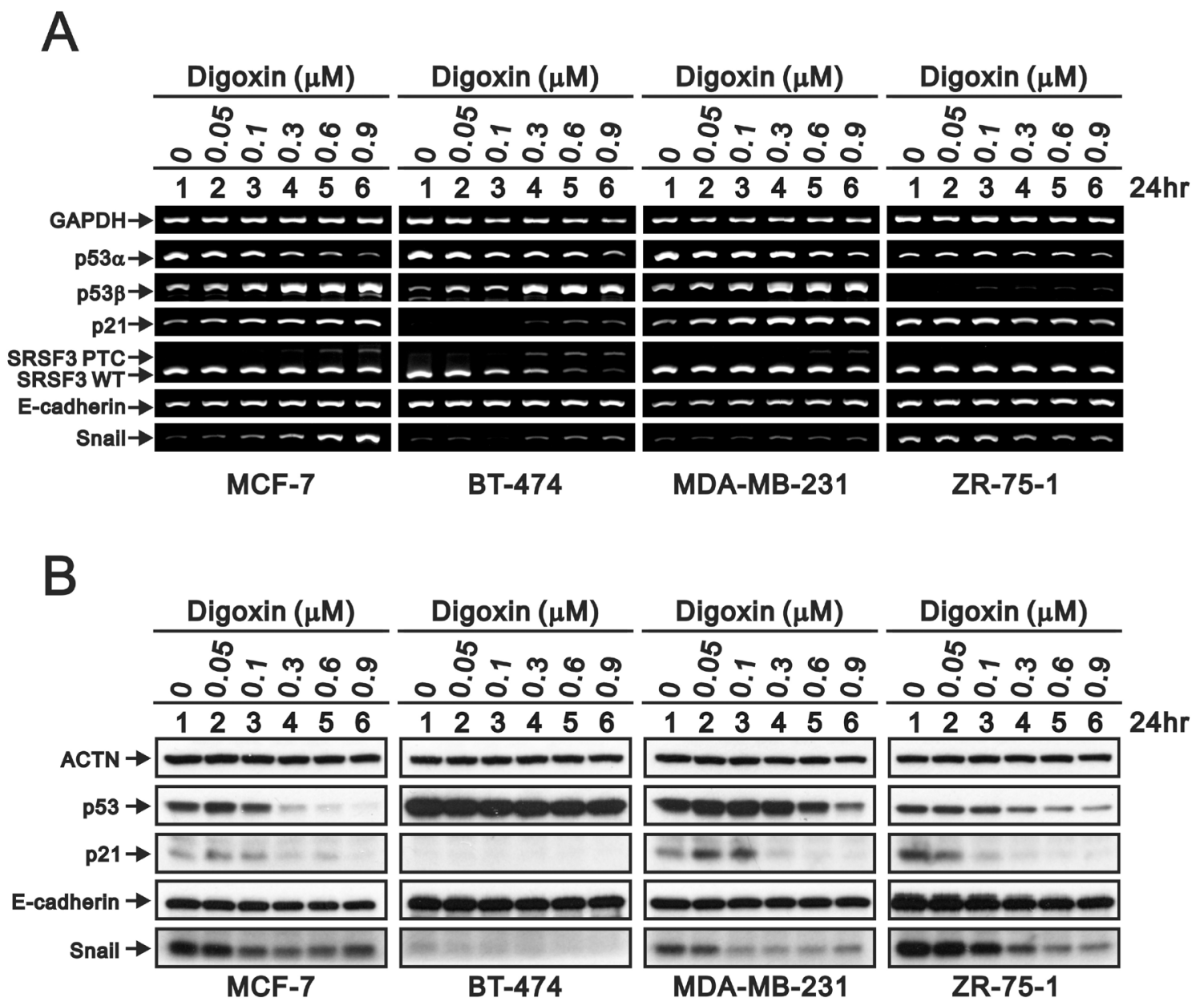

Figure 4: Potential effects of digoxin on the target mRNAs and proteins in breast cancer cells. Four breast cells were treated with indicated concentrations of digoxin for $24 \mathrm{~h}$. The cells were collected and subjected to (A) RT-PCR analysis of p53 $\alpha$, p53 $\beta$, p21, SRSF3, E-cadherin, Snail, and GAPDH (loading control) expression, (B) the Western blot analysis for the detection of p53, p21, E-cadherin, Snail, and ACTN (loading control). The results are representative of two independent experiments. 
dietary habits, and other stressful psychosocial events which could be related to cancers. However, our study explored a large sample in Taiwan, and used a reliable model to focus on the relationship between digoxin and cancers.

Our cell-line based results may not be clinically relevant to the general breast cancer population [27]. However, this strategy allows us to consider some possibilities from the clinical findings. The strategy of combining clinical big data with necessary basic research will help us focus on the detailed mechanisms to understand complicated clinical issues and drug usage.

\section{MATERIALS AND METHODS}

\section{Data source}

This study utilized data retrieved from the National Health Insurance Research Database (NHI-RD) between January 1, 2000 and December 31, 2000, which contains all the data regarding claims from Taiwan's NHI program. All medical care providers are required to provide outpatient and inpatient services to those insured to claim their fees from the NHI program [19]. The medical claims information includes data on patient demographics, clinical details (disease and procedure codes according to the International Classification of Disease $9^{\text {th }}$ version (ICD-9-CM)), and healthcare use (days in hospital, drug use, and charges). The National Health Research Institute (NHRI) maintains the database and releases identified secondary data to scientists and clinicians for research purposes.

\section{Study sample}

This retrospective study included a study cohort and a comparison cohort. The study cohort was aged $>18$ years with a first diagnosis of heart failure (ICD9-CM codes 428.xx, 398.91, 402.01, 402.11, 402.91, 404.00, 404.01, 404.03, 404.10, 404.11, 404.13, 404.90, 404.91, 404.93) between January 1, 2000 and December 31,2000 . Our study cohort are patients with heart failure who have taken digoxin (pHF-Digo) pHF-Digo. To ensure the study cohort consists of patients with a diagnosis of heart failure disease and digoxin consumption, patients were included if they had been prescribed DDDs of digoxin in 2000. Also, patients were considered as having continued digoxin therapy if less than 3 months had elapsed between prescriptions [31]. The digoxin included DIGOXIN INJECTION, LANOXIN DIGOXIN TABLETS, LANOXIN DIGOXIN INJECTION, or CARDIACIN ELIXIR [32]. Since the maintenance dose of LANITOP TABLETS is $0.1 \mathrm{mg}$ /day, which differs from $0.125 \sim 0.75 \mathrm{mg} /$ day of the other four types of digoxin [33], we excluded LANITOP TABLETS to avoid bias. The first prescription of digoxin for each patient was assigned as the index date. The exclusion criteria for pHF-Digo were as follows: (1) a previous diagnosis of heart failure before 2000; (2) with a previous cancers index date; and (3) the cancer(s) index date was within 2 years after a prescription for digoxin. The reason or this is that there is likely a latency period of at least 2 years between exposure and the development of a clinically significant cancer [34]. The study cohort included 1,219 patients.

The comparison cohort ( $\mathrm{pHF}$ ) was extracted from the remaining beneficiaries of the database in and included patients aged $>18$ to limit the study to an adult population. The urbanization level of the residence for each patient was defined as urban, suburban, or rural [35]. Urbanization was evaluated to ensure that the patients had reasonably similar socioeconomic characteristics. Information on preexisting comorbidities was acquired from CCI scores. The CCI is a scoring system that assigns points from 1-6 to a range of diseases [36]. A CCI score of 3 was used as the cutoff score to divide the subjects into two groups according to the sum of their points: $<3$ points (low comorbidity) and $\geq 3$ points (high comorbidity) [37]. The index date of a (pHF) was defined as the first use of medical care within the index year for each patient. The comparison cohort included 2,942 patients.

\section{Variables of interest}

The risk of cancer (ICD-9-CM codes 140.XX-208. $\mathrm{XX}$ ) was evaluated for each patient. Patients with heart failure were followed up from their first prescription of digoxin index to the first diagnosis of cancer, death, or the end of follow up. The patients were individually followed up for 10-year medical records.

\section{Statistical analysis}

SAS statistical package (SAS systems for Windows, version 9.2; Cary, NC, USA) was used to perform analyses. Demographic information such as age, sex, income, residential region, and urbanization level was acquired from each patient's file in the NHI database. Age was divided into 3 groups: < 45, 45-65, and > 65 years. Average monthly income was divided into 3 groups: < US\$640 (New Taiwan Dollars (NTD) 40,000), US\$ 640-1280 (NTD 20,000-39,999), and $\geq$ US\$ 1281 $(\geq$ NTD 40,000). The residential areas of patients were divided into the 4 regions of Taiwan: northern, central, southern, and eastern. The urbanization level was divided into urban, suburban, and rural. An incident case was defined as a patient who was using NHI services for the first time, was diagnosed as a new case with a heart failure disease in 2000, and had not previously been diagnosed with cancer. The incidence density was calculated as the number of incident cases relative to the number per 100 person-years contributed by the subjects of this study. All patients were followed from January 1, 2000 to the date of 
cancer diagnosis and the data were censored at the date of death or emigration or on December 31, 2010, whichever came first [38]. The Kaplan-Meier method and log-rank test were used to assess the differences in the survival rates and curves, respectively. We studied the development of cancers between pHF-Digo and pHF. A univariate Cox proportional hazard regression was conducted to estimate the CHRs of cancers related to heart failure disease. After controlling for potential confounders of cancers, including age, gender, income, urbanization, and CCI score. A multivariate Cox proportional hazard regression model was applied to calculate the AHRs, which indicated the independent effects of long-term digoxin consumption on the hazard of cancers. A $P$ value $<.05$ was considered statistically significant.

\section{Ethical approval}

This study has been granted an exemption from requiring ethics approval by the Taiwan Medical University-Joint Institutional Review Board (approval number: 201405028).

\section{Cell culture and survival analysis}

MCF-7, BT474, MDA-MB-231, and ZR-751 cells were cultured in Dulbecco's modified Eagle's medium supplemented with $10 \%$ fetal bovine serum and $1 \%$ penicillin-streptomycin (Invitrogen, USA). For cell survival analysis using the MTS (3-(4,5-dimethylthiazol2-yl)-5-(3-carboxymethoxyphenyl)-2-(4-sulfophenyl)-2Htetrazolium) assay, cells were seeded in 96-well culture plates and could grow for the indicated periods of time. The MTS assay reagent is composed of MTS and the electron coupling agent phenazine methosulphate (PMS). The $400 \mu \mathrm{l}$ MTS/PMS solution was added to each well and the plate was incubated for $3 \mathrm{~h}$ at $37^{\circ} \mathrm{C}$. Transfer 100 $\mu \mathrm{l}$ aliquots of each sample and the absorbance at $490 \mathrm{~nm}$ was measured using an ELISA plate reader (Multiskan EX, Thermo, USA). As a control, cells treated with media containing no compounds were set as $100 \%$ cell survival.

\section{Fluorescence-activated cell sorting (FACS) and proliferation analysis}

For cell cycle evaluation and cellular proliferation analysis, cells were incorporated in bromodeoxyuridine (BrdU) and flow cytometric analysis, and then processed with the FITC-BrdU Flow Kit per the manufacturer's instructions (BD Biosciences) with specific anti-BrdU fluorescent antibodies. Total DNA was stained with 7-aminoactinomycin D (7-AAD). With this combination, two-color flow cytometric analysis permits the enumeration and characterization of cells that are actively synthesizing DNA (BrdU incorporation as the proliferation rate) in terms of their cell cycle position (i.e., G0/1, S, or $\mathrm{G} 2 / \mathrm{M}$ phase defined by 7-AAD staining intensities). The data were analyzed using the CellQuest Pro software package (BD Biosciences) as previously described [39].

\section{Reverse transcription-polymerase chain reaction (RT-PCR)}

Total RNA was isolated using the TRIsure (BIOLINE, UK) reagent followed by the manufacturer's instructions. One microgram of total RNA was subjected to reverse transcription using MMLV reverse transcriptase (Epicentre Biotechnologies, USA) for $60 \mathrm{~min}$ at $37^{\circ} \mathrm{C}$. The PCR reactions were run on a GeneAmp PCR system 9700 (Applied Biosystems, USA). All PCR primer sequences (Table 6).

\section{Western blot analysis}

Cell lysates were prepared in lysis buffer $(100 \mathrm{mM}$ Tris- $\mathrm{HCl}$ of $\mathrm{pH} 8.0,150 \mathrm{mM} \mathrm{NaCl}, 0.1 \%$ SDS, and $1 \%$ Triton X-100) at $4^{\circ} \mathrm{C}$. The cell extracts were separated by SDS-PAGE, transferred onto a polyvinylidene difluoride membrane (Millipore, USA) and detected using antibodies against $\alpha$-actinin (ACTN), p53, p21, snail (Santa Cruz Biotechnology, USA), and E-cadherin (BD, USA).

\section{Abbreviations}

HF, heart failure; ER, estrogen receptor; NHI, National Health Insurance; NHIRD, National Health Insurance Research database; DDDs, defined daily doses; CCI, Charlson Comorbidity Index; NTD, New Taiwan Dollars; CHRs, crude hazard ratios; AHRs, adjusted hazard ratios; PMS, phenazine methosulfate; BrdU, bromodeoxyuridine; 7-AAD, 7-aminoactinomycin D; PR, progesterone receptor.

\section{Authors' contributions}

MHC conceived and carried out experiments, analyzed data and wrote the paper. YWW conceived and carried out experiments and analyzed data. YLC conceived and carried out experiments and analyzed data. SMH conceived of the study and helped to draft the manuscript. WSL conceived of the study, and participated in its design and coordination and helped to draft the manuscript. All authors read and approved the final manuscript.

\section{ACKNOWLEDGMENTS}

This work was supported by grants from the National Defense Medical Bureau [MAB-104-49, MAB105-09 to S-M HUANG; MAB-104-48, MAB-105-14 
to W-S LIN], the Ministry of Education [1040097366B to M-H Chung], Taiwan, ROC.

\section{CONFLICTS OF INTEREST}

All authors declare that there are no conflicts of interest.

\section{REFERENCES}

1. Bagrov AY, Shapiro JI, Fedorova OV. Endogenous cardiotonic steroids: physiology, pharmacology, and novel therapeutic targets. Pharmacological Reviews. 2009; 61:9-38.

2. Schoner W, Scheiner-Bobis G. Endogenous and exogenous cardiac glycosides and their mechanisms of action. American Journal of Cardiovascular Drugs. 2007; 7:173-189.

3. Schoner W, Scheiner-Bobis G. Endogenous and exogenous cardiac glycosides: their roles in hypertension, salt metabolism, and cell growth. American Journal of Physiology Cell Physiology. 2007; 293:C509-536.

4. Menger L, Vacchelli E, Adjemian S, Martins I, Ma Y, Shen S, Yamazaki T, Sukkurwala AQ, Michaud M, Mignot G, Schlemmer F, Sulpice E, Locher C, et al. Cardiac glycosides exert anticancer effects by inducing immunogenic cell death. Science Translational Medicine. 2012; 4:143ra199.

5. Elbaz HA, Stueckle TA, Tse W, Rojanasakul Y, Dinu CZ. Digitoxin and its analogs as novel cancer therapeutics. Experimental Hematology \& Oncology. 2012; 1:4.

6. Kulikov A, Eva A, Kirch U, Boldyrev A, Scheiner-Bobis G. Ouabain activates signaling pathways associated with cell death in human neuroblastoma. Biochimica et Biophysica Acta. 2007; 1768:1691-1702.

7. Perne A, Muellner MK, Steinrueck M, Craig-Mueller N, Mayerhofer J, Schwarzinger I, Sloane M, Uras IZ, Hoermann G, Nijman SM, Mayerhofer M. Cardiac glycosides induce cell death in human cells by inhibiting general protein synthesis. PloS One. 2009; 4:e8292.

8. Lu GY, Liu ST, Huang SM, Chang YL, Lin WS. Multiple effects of digoxin on subsets of cancer-associated genes through the alternative splicing pathway. Biochimie. 2014; 106C:131-139.

9. Murdoch TB, Detsky AS. The inevitable application of big data to health care. JAMA. 2013; 309:1351-1352.

10. Stenkvist B. Is digitalis a therapy for breast carcinoma? Oncology Reports. 1999; 6:493-496.

11. Ahern TP, Lash TL, Sorensen HT, Pedersen L. Digoxin treatment is associated with an increased incidence of breast cancer: a population-based case-control study. Breast Cancer Research. 2008; 10:R102.

12. Biggar RJ. Molecular pathways: digoxin use and estrogen-sensitive cancers--risks and possible therapeutic implications. Clinical Cancer Research. 2012; 18:2133-2137.

13. Niraula S, Pond G, de Wit R, Eisenberger M, Tannock IF, Joshua AM. Influence of concurrent medications on outcomes of men with prostate cancer included in the TAX 327 study. Canadian Urological Association journal. 2013; 7:E74-81.

14. Platz EA, Yegnasubramanian S, Liu JO, Chong CR, Shim JS, Kenfield SA, Stampfer MJ, Willett WC, Giovannucci E, Nelson WG. A novel two-stage, transdisciplinary study identifies digoxin as a possible drug for prostate cancer treatment. Cancer Discovery. 2011; 1:68-77.

15. Biggar RJ, Andersen EW, Kroman N, Wohlfahrt J, Melbye M. Breast cancer in women using digoxin: tumor characteristics and relapse risk. Breast Cancer Research. 2013; 15:R13.

16. Biggar RJ, Wohlfahrt J, Oudin A, Hjuler T, Melbye M. Digoxin use and the risk of breast cancer in women. Journal of Clinical Oncology. 2011; 29:2165-2170.

17. Carey LA, Perou CM, Livasy CA, Dressler LG, Cowan D, Conway K, Karaca G, Troester MA, Tse CK, Edmiston S, Deming SL, Geradts J, Cheang MC, et al. Race, breast cancer subtypes, and survival in the Carolina Breast Cancer Study. JAMA. 2006; 295:2492-2502.

18. Menger L, Vacchelli E, Kepp O, Eggermont A, Tartour E, Zitvogel L, Kroemer G, Galluzzi L. Trial watch: Cardiac glycosides and cancer therapy. Oncoimmunology. 2013; 2:e23082.

19. Wang WM, Liu ST, Huang SM, Lin WS, Chen SG, Chang YL. Zac1 functional interactions mediate AP-1 transcriptional activity. Biochimica et Biophysica Acta. 2011; 1813:2050-2060.

20. Lu GY, Huang SM, Liu ST, Liu PY, Chou WY, Lin WS. Caffeine induces tumor cytotoxicity via the regulation of alternative splicing in subsets of cancer-associated genes. The International Journal of Biochemistry \& Cell Biology. 2014; 47:83-92.

21. Anderson ES, Lin CH, Xiao X, Stoilov P, Burge CB, Black $\mathrm{DL}$. The cardiotonic steroid digitoxin regulates alternative splicing through depletion of the splicing factors SRSF3 and TRA2B. RNA. 2012; 18:1041-1049.

22. Wang Z, Zheng M, Li Z, Li R, Jia L, Xiong X, Southall N, Wang S, Xia M, Austin CP, Zheng W, Xie Z, Sun Y. Cardiac glycosides inhibit p53 synthesis by a mechanism relieved by Src or MAPK inhibition. Cancer Research. 2009; 69:6556-6564.

23. Ahern TP, Tamimi RM, Rosner BA, Hankinson SE. Digoxin use and risk of invasive breast cancer: evidence from the Nurses' Health Study and meta-analysis. Breast Cancer Research and Treatment. 2014; 144:427-435.

24. Calderon-Montano JM, Burgos-Moron E, Orta ML, Maldonado-Navas D, Garcia-Dominguez I, LopezLazaro M. Evaluating the cancer therapeutic potential of 
cardiac glycosides. BioMed Research International. 2014; 2014:794930.

25. Slingerland M, Cerella C, Guchelaar HJ, Diederich M, Gelderblom H. Cardiac glycosides in cancer therapy: from preclinical investigations towards clinical trials. Investigational New Drugs. 2013; 31:1087-1094.

26. The effect of digoxin on mortality and morbidity in patients with heart failure. The New England Journal of Medicine. 1997; 336:525-533.

27. Holliday DL, Speirs V. Choosing the right cell line for breast cancer research. Breast Cancer Research. 2011; 13:215.

28. Subik K, Lee JF, Baxter L, Strzepek T, Costello D, Crowley P, Xing L, Hung MC, Bonfiglio T, Hicks DG, Tang P. The Expression Patterns of ER, PR, HER2, CK5/6, EGFR, $\mathrm{Ki}-67$ and AR by Immunohistochemical Analysis in Breast Cancer Cell Lines. Breast Cancer. 2010; 4:35-41.

29. Troester MA, Herschkowitz JI, Oh DS, He X, Hoadley KA, Barbier CS, Perou CM. Gene expression patterns associated with p53 status in breast cancer. BMC Cancer. 2006; 6:276.

30. Ni T, Li XY, Lu N, An T, Liu ZP, Fu R, Lv WC, Zhang YW, Xu XJ, Grant Rowe R, Lin YS, Scherer A, Feinberg T, et al. Snail1-dependent p53 repression regulates expansion and activity of tumour-initiating cells in breast cancer. Nature Cell Biology. 2016; 18:1221-1232.

31. Wang MT, Su CY, Chan AL, Lian PW, Leu HB, Hsu YJ. Risk of digoxin intoxication in heart failure patients exposed to digoxin-diuretic interactions: a population-based study. British Journal of Clinical Pharmacology. 2010; 70:258-267.

32. Fang SY, Chen CY, Chang IS, Wu EC, Chang CM, Lin KM. Predictors of the incidence and discontinuation of long-term use of benzodiazepines: a population-based study. Drug and Alcohol Dependence. 2009; 104:140-146.

33. Fan Z-X. (2005). The newest medicine manual in 2005: Gau-Hwua Publisher.

34. Su VY, Hu YW, Chou KT, Ou SM, Lee YC, Lin EY, Chen TJ, Tzeng CH, Liu CJ. Amiodarone and the risk of cancer: a nationwide population-based study. Cancer. 2013; 119:1699-1705.

35. Liu CY HY, Chuang YL, Chen YJ, Weng WS, Liu JS, Liang KY. Incorporating development stratification of Taiwan townships into sampling design of large scale health interview survey. Journal of Health Management. 2006; 4:22.

36. Thygesen SK, Christiansen CF, Christensen S, Lash TL, Sorensen HT. The predictive value of ICD-10 diagnostic coding used to assess Charlson comorbidity index conditions in the population-based Danish National Registry of Patients. BMC Medical Research Methodology. 2011; 11:83.

37. Charlson ME, Pompei P, Ales KL, MacKenzie CR. A new method of classifying prognostic comorbidity in longitudinal studies: development and validation. Journal of Chronic Diseases. 1987; 40:373-383.

38. Nielsen SF, Nordestgaard BG, Bojesen SE. Statin Use and Reduced Cancer-Related Mortality. New England Journal of Medicine. 2012; 367:1792-1802.

39. Chang YL, Lee HJ, Liu ST, Lin YS, Chen TC, Hsieh TY, Huang HS, Huang SM. Different roles of p53 in the regulation of DNA damage caused by 1,2-heteroannelated anthraquinones and doxorubicin. The International Journal of Biochemistry \& Cell Biology. 2011; 43:1720-1728. 